\title{
Children of God in Bergen
}

\author{
By KARIN KVIDELAND
}

The founder of the movement, David Berg, was born in Melrose, Oakland, Calif. on the 18th of February 1919. In his book "Survival, the true story of Moses and the Children of God" he says about himself: "During the first years of my life there was little to indicate that greater things were about to happen, except these strange prophecies." What he means by this, he explains as follows: "It was said that I would achieve many great things and several of these are already fulfilled [...] There were prophecies claiming that I would become like Moses, Jeremiah, Ezekiel, Daniel and even David in the task set before me by God."' Berg describes himself as a "real bookworm" 3 who "loved to be alone". ${ }^{4}$ "I could spend hours and days in studying the beauty and miracles in God's nature and in listening to his silent voice, which explained what I saw." In spite of this somewhat dreamy attitude the boy was rather good at school. When he left Montery Union High School it was with the best diploma ever given during the 80 years the school had existed. ${ }^{6}$ Berg did not choose an academical career as his grandfather, his father and brother, all named Hjalmar E. Berg, had done. God continued to be his first love, he says, "and with all my heart, I wished to serve Him and others in the place for which he thought me most fit". ${ }^{7}$

Berg's family travelled a lot both through America and Canada, working also as missionaries. They were poor and lived in old cars, tents and caravans. Mainly they visited California, Texas, Oklahoma, Ontario, Pennsylvania, Washington D.C. and Florida. In 1924 (David Berg was then 5 years

\footnotetext{
1 Moses 1973, 36.

2 Ib., 35.

${ }^{3}$ Ib., 36.

4 Ib.

5 Ib.

${ }^{6}$ Cf. ib.

7 Ib., 37.
} 
old) the family settled in Miami, Florida. ${ }^{8}$ There his parents built "the greatest evangelical tabernacle in the southeastern part of the United States". ${ }^{9}$ A wave of revival arose and lasted until the crash in $1925 .{ }^{10}$ David Berg mentions a tremendous hurricane which destroyed the tabernacle and a large part of Miami. His parents interpreted this event as an urge to intensify their missionary efforts. About the religious atmosphere of his home Berg gives rather detailed information in "Survival", but he is less communicative about his years at school. When he had finished the "gymnasium"; he does not say which, nor when he left, his family had moved to California. ${ }^{11}$ Now they gave all their time to missionary work and Berg assisted them.

The next chronological date we hear of in "Survival", is 1941; Berg is drafted for military service, shortly after the bombing of Pearl Harbor. However, he is soon dismissed again "as completely unfit" because of heart-trouble. The army informs his family of the serious state he is in, it is understood that he will die soon and Berg is sent home in high fever. "But when I finally promised God to serve him truthfully all my life if He would save my heart, I was cured immediately like an answer to prayer." 12 Instantly he started to fulfill his promise and refused to stay in bed any longer. He silenced the protesting family by saying: "If God wished him to work, He would have to take care of his heart." ${ }^{13} \mathrm{He}$ started on full-time missionary work, his health improved more and more and in 1944 he married.

1949 Berg raises a church in Valley Farm, Arizona, where he worked for two years as a minister, ordained by the "Christian and Missionary Alliance". He does not express himself exclusively in positive terms about this particular period of his life. His congregation was a mixed one, consisting of Southerners, Indians and Mexicans. There were controversies among these different groups, and as time went by there arose difficulties also between the minister and his white employers. Berg traces them back to his "integrational policy and radical preaching". ${ }^{14}$ The latter aimed at the rich people sharing their riches with the poor. This, together with the fact

\footnotetext{
${ }^{8}$ Cf. ib.

${ }^{9} \mathrm{Ib}$.

10 Cf. ib.

11 Cf. ib., 38.

12 Ib., $39 \mathrm{f}$.

13 Ib., 40.

14 Ib., 42.
} 
that Berg refused to whitewash the Church he had built, led to his being fired. ${ }^{15}$ Suddenly he was without a job, without money, without a place to live. He, his three children and his wife, expecting her fourth, found themselves without support. This experience and his conviction that "the clerical system was ineffective and contrary to the Bible", besides being "politically corrupt" and the fact that the members of the church led hypocritical lives caused him to turn against the church: "I got so enraged, bitter and sick with the whole hypocritical church-system, that I nearly became a communist." 16

However, instead of following this intention, Berg went back to the university. This was made possible by a special law that supported those who had been in the army. This time Berg chose philosophy, psychology and state-administration as subjects. "Mainly I studied socialism and communism." "17 But soon he realized that "the so-called altruistic aims of these political systems never could be reached without the love of God in the hearts of men, which we find in the genuine communism of the first church, and which was only effective through the power of the Spirit of God!' ${ }^{18}$ Berg also formed the opinion that a democratic government will never be able to produce a perfect rule, complete peace on earth, just economy, healthy ecology, God-fearing education or just religion. ${ }^{19}$ This will only be achieved, according to Berg, when Jesus returns and establishes his kingdom with authoritative government and complete justice on earth. ${ }^{20}$ The Bible predicts that there will appear a totally godless and anti-christian world-government. Those who will not cooperate with the devil-possessed incarnation of Satan, the ruler of the world, will be hunted, prosecuted and slaughtered according to his orders. Only those who bear the sign of God on their foreheads will be saved, "we [...] who have experienced this supernatural spiritual rebirth by God's love in Jesus". ${ }^{21}$

Berg spent several years at different universities and finally found that "it will be impossible to prepare the Christians for what is coming by the means

\footnotetext{
15 Cf. ib.

${ }^{16} \mathrm{Ib}$.

${ }_{17} \mathrm{Ib}, 44$.

$18 \mathrm{Ib}$.

${ }^{19}$ Cf. ib., 46.

${ }^{20} \mathrm{Cf}$. ib.

${ }^{21} \mathrm{Ib} ., 47$.
} 
used in the churches today!' 22 During the three-years period he was working as a teacher, he learned a good deal about youth and decided to save them from their horrible fate as guiltless victims of a fiendish and godless system. He started this saving process in his own house, where he taught his own children to share with others. He asked them to go out and find the poor and to bring them home. And "true, voluntary, genuine and unselfish Christian sharing did really function on a small scale". ${ }^{23}$ "Our ideal and example was the simple communism of the first church, and it did the same thing to us as it did to them. ${ }^{24}$

Between the late forties and 1968, when the movement started, Berg claims to have received several revelations. These started with the "Key of David", the title refers to Rev. 3, 7-8: "These things saith he that is holy, he that is true, he that hath the key of David, he that openeth, and no man shutteth; and shutteth, and no man openeth; I know thy works; behold, I have set before thee an open door, and no man can shut it: for thou hast a little strength, and hast kept my word, and hast not denied my name." Berg interprets this as an indication of his future work of witnessing against the church. ${ }^{25}$ In 1952 he receives the "Call of Ezekiel", in 1962 the "Message of Jeremiah". ${ }^{26}$ The latter he understands as God's last warning to a doomed nation and God's plan for His prophets in such a time. However, Berg is not the only one who receives revelation. In 1965 his mother got the "warning revelation" which is concerned with the "great confusion" about to come. 1966 she prophesied that her son had been favoured with the "understanding of Daniel", that means that he would be able to understand the number of years until the end of destruction. ${ }^{27}$

But first in 1968 David Berg was convinced that he should take up work among the Hippies in Huntington Beach, Calif. His mother urged him to come to this place and do something for these people. Berg did so and "the Jesus revolution started with a gang of wild, red radicals from some of the lowest strata of human society", 28 "our time's most despised generation". "The church-people did not know how to handle them; even if some of them

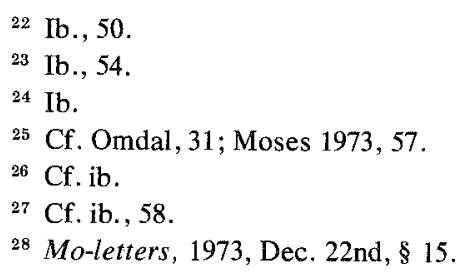


at least tried with a small coffee-house, Teen-Challenge in the heart of the town." 29 According to the author of the article "Whose Children?",30 "the beginnings of the Children are already obscured by legend. The core of initial apostles seems to have gathered around a fundamentalist preacher named David Berg, [...] his four children and their mates."

In 1969 their first congress takes place in Laurentide near Montreal. Here the followers of Berg establish themselves as a religious group. Bishops and elders were elected, Berg is called Moses, under which name he was referred to in the revelations of some of his young followers. The group is called Children of God, a name first used by a journalist and then adopted by them. The number of members is increasing, but there seems to be no agreement on the exact figure. Newsweek ${ }^{31}$ mentions 3000 . Time $^{32} 2000$ while my informant in Bergen claims that now, in 1974, there are approximately 4000 of them. Another issue of Time $^{33}$ gives their number as 3000 and states that few of them are still living in America.

The missionary efforts of the group are mainly directed towards the younger generation. Usually the members are in their late teens and early twenties. When joining the movement, they forsake everything. That means they leave school or universities, they give up other forms of training, they don't continue with their jobs and they leave their homes. They live together in communes, or as they prefer to call it "Christian houses". ${ }^{34}$ The forsaking even goes a step further: the converts turn over their wordly possessions to the sect's elders and bishops. ${ }^{35}$ In America all this had led to the forming of a "Parent's Committee to Free Our Sons and Daughters from the Children of God". ${ }^{36}$ The committe was founded by Mr. Rambur, whose daughter had joined the group. Mr. Rambur states that he has nothing against the beliefs of the group, but he and his committee are strongly opposed to the authoritative control practised by the sect. From the already mentioned article in Newsweek ${ }^{37}$ it appears that "once youngsters join the

\footnotetext{
29 Moses 1973, 59.

30 Time, 1972, Jan. 24th.

${ }^{31}$ Cf. Newsweek, 1971, Nov. 22nd.

32 Cf. Time, 1972, Jan. 24th.

${ }^{33}$ Cf. ib. 1974, Feb. 18th.

${ }^{34}$ Ib. 1971, June 21st.

${ }^{35}$ Cf. Newsweek, 1971, Nov. 22nd.

$36 \mathrm{Ib}$.

${ }^{37}$ Cf. ib.
} 
Children's chanting, praying communes of Christian fundamentalists, they are forbidden to go home again, and elders of the sect censor their mail and monitor phone calls from their parents". My informants denied the truth of such an accusation. On the contrary, according to them, relationship with the parents often improved after conversion. The members of the Bergen family stress the point that they encourage contact between the members and their families. They referred to the "Revolutionary Rules", where I would find that members should maintain contact with their parents. The rules however, contain nothing of the sort.

Not all parents take a negative view of the sect. The article in Newsweek $^{38}$ also presents what Mr. M. J. DuPuy, a Houston industrialist, has to say. One of his sons had dropped out of school and resisted all psychiatric efforts to get him off hard drugs. Then he disappeared with the Children of God and was cured. Months later, another of DuPuy's sons joined the sect, and after visiting the boys DuPuy was won over. "They had gotten turned onto Christ and saved, [...] I realized then that the Children of God were doing something for these kids that money just couldn't buy." In Time's article of 1972 another father expresses his positive opinion of the group: "they are totally without guile, without games. They really believe. They are prepared to die."

For a year and a half Moses, the leader of the group, maintained a connection with the TV-evangelist G. F. Jordan. Moses was permitted by Jordan to use his properties in Texas and California for the Children. In return, Jordan was allowed to show the converts on TV. Disagreements over the properties broke the relation between Moses and Jordan and the latter ordered the Children off his land. Thus we read in Time. ${ }^{39}$ In "Survival" Moses gives a more detailed account of the growth of the colony in Los Angeles and Jordan's success on TV. His income made it possible to buy two farms for the Children of God. This money, Moses claims, was collected by Jordan on behalf of the Children. But they were only allowed to use the smaller, poorly equipped farm while they had to work rather hard on the other, the weekend place of the Jordan family. ${ }^{40}$ During the stay in Texas and especially after the clash with Jordan, the idea of forming colonies all over the world occurred to them for the first time. ${ }^{41}$

उs Cf. ib.

39 Cf. Time, 1972, Jan. 24 th.

$40 \mathrm{Cf}$. Moses 1973, 85.

41 Cf. Omdal, 36. 
In 1972 the movement reached Europe. A colony was founded in London, and from there they proceeded to Oslo. "The young American revolutionists were allowed to move into a house belonging to Oslo Indremisjon where they formed the first Norwegian Jesus-collective." ${ }_{42}$ In April/May 1972 they reached Bergen. At that time however, they had no success there, and Bergen was given up until June 1973. Today, the family in Bergen consists of 6 members living in a commune and they have contact with $10-20$ persons, a few of whom may join them sooner or later. This information I got at my first interview in May 1974. When I visited them again in June, the family counted two more members. They are: Heidi, Jonas, Berenica, Lystra, Abel, Mirjam, her daughter aged two and Samuel. I did not meet all of them, but asked Heidi, Berenica, Lystra and Abel why they had joined, where they came from, what they had previously been doing. It turned out that one of them, Abel, was well acquainted with a Christian milieu already before he met the Children. His parents belong to a Pentecostal congregation and from early childhood on he was familiar with it. What he met with there, however, could not satisfy his need for love. Abel considers himself to be a person in need of a great deal of care and affection. Another objection was that almost everything was forbidden, he was unhappy there and left the congregation. He tried several other organisations in Oslo, among them Maranatha, The Salvation Army and even the church, but he did not find there what he was looking for.

Mirjam, Lystra and Berenica had no religious background at all. They state that they either were against Christianity or indifferent towards it. While talking to them, I got the impression that they had been unhappy in their former situation. Some of them had been using drugs, relations with parents had been unsatisfactory. Mirjam was unable to meet the demands of her job, and until they met the Children, they thought life meaningless. Heidi, the leader of the Bergen family, characterizes those that join the group as misfits, unable to find their place in society. "We want to show them that there is another way of life." 43

What makes these "testimonies" conspicuous, is the striking similarity of the formulations. Anyone familiar with the group's "literature" will easily recognize formulations and expressions taken from these booklets in what the Children say. In "Revolution for Jesus", the movement's program,

${ }^{42}$ Ib., 9.

${ }_{43}$ Heidi, interview, 1974, June 11th. 
Moses David says: "The first step is a thought- and prayerful election of truthful men. The second to give them a glowing vision and the third to send men out to make new disciples." ${ }_{44}$ Moses has apparently succeeded with the second point of his program, the glowing vision. They consider themselves as strangers and pilgrims in this world, they are saved and burning with desire to save as many as possible of the young generation before the end comes. They do this by being "full-time revolutionary workers"'. Why only the young? The Children's answer is: "It is impossible to put new wine into old bottles." With this phrase they mean to express that older people are usually rather set in their accustomed way of thinking, so that it would not lead to anything to try to change them. They would not win new members from the older generation. This leads to the third point of the program, the sending of missionaries. New members mean more revolutionary workers. Their training starts immediately after having joined. A large part of this training consists of learning the Bible by heart. This gives them an abundant store of Biblical phrases, ready at hand when campaigning in the street. Besides this the Mo-letters, pamphlets written by Moses David, are read and discussed in common and they are instructed how to witness. As soon as the new members are considered capable of performing their new task, they are sent out two and two to win new followers.

According to an early report in Newsweek ${ }^{45}$ the Children of God "are a highly disciplined, apocalyptic sect within the youthful 'Jesus movement' ". The revolutionary rules ${ }^{46}$ allow "no smoking or petting, merely to greet one another with a holy kiss-and absolutely no dates. Marriage only for members after months of service, ready to stand on their own and with the approval of the group."

This year however, the report found in Time ${ }^{47}$ draws a different picture: Today the Children of God are loosening up their sex ethics enough to lure new members. In Great Britain Children of God evangelists are preaching a sexual-freedom line unusual for the Jesus Movement. "Masturbation and premarital sex, for example, are now only sinful if indulged in 'too much', like 'hiking, swimming or exercising too much'. Polygamy is also condoned though not recommended. In Stoke on Trent, COG [Children of

\footnotetext{
${ }_{44}$ Moses 1972, 29.

${ }^{45}$ Newsweek, 1971, Nov, 22nd.

${ }_{46}$ Moses 1972, 21.

${ }_{47}$ Cf. Time, 1974, Feb. 18th.

11-752446 H. Biezais
} 
God] pitchmen greet the uninitiated temptingly: "Want to read something sexy, something that'll turn you on?" I wondered how my informants would take accusations like these and asked for their opinion. "There are two possibilities, I was told, either it is a damned lie, or the author has misunderstood the matter." "A suggestion like 'want to read something sexy', does not necessarily imply a pornographic meaning." According to a member of the Bergen group, ${ }^{48}$ it may be a conscious effort to get people interested in the pamphlet. Strangely enough, my informants considered this particular article in Time a good one, they seemed not at all embarrassed by the accusations put forward in it. Even more astonishing was the answer of another member who cited Rom. 14: 14. "I know, and am persuaded by the Lord Jesus, that there is nothing unclean of itself: but to him that esteemeth any thing to be unclean, to him it is unclean." Still, it provokes curiosity if a movement originally favouring very strict rules in connection with sexual behaviour, now deviates from these rules. There must be a reason for this change of attitude. In the literature of the Children of God evidence is found indicating at least one reason. It has already been mentioned that one of the demands new members meet, is to "forsake everything". Among many other things this also includes the giving up of one's job. That means one is without any regular income. Being without income however, does not imply no longer having any expenses. Moses David solves this problem by starting with the justified question: "How did Jesus pay bills, being without a job?"' The answer is given in Matt. 17:27: "Notwithstanding, lest we should offend them, go thou to the sea, and cast an hook, and take up the fish that first cometh up; and when thou hast opened his mouth, thou shalt find a piece of money: that take, and give unto them for me and thee." Moses draws a somewhat surprising conclusion from this text: "The fish is new disciples." 49 The financing program for his colonies he finds in Matt. 4: 19, where Jesus urges Peter and Andrew: "Follow me, and I will make you fishers of men." The Children of God attach great importance to living in communes. "To have everything in common and brotherly love with ONE HEART and ONE SOUL is the key to success in God's movement." In Jerusalem they sold everything and placed the money at the feet of the leaders, who distributed it to everyone according to his need. This will also

\footnotetext{
${ }^{48}$ Samuel, member of the Bergen family.

49 Moses 1972, 32.

so Cf. ib., 17.
} 
function today, Moses claims, the money to be distributed comes from new followers. So far, one may enter into the line of his thought, but what follows, causes uneasiness: "Therefore it is impossible for us to stop growing. We have to increase to manage financially." 51

This shows that there are several reasons for winning new members. One is "saving tomorrow's youth from their horrible fate as guiltless victims of a fiendish and godless social, educational, economic and religious system". ${ }^{22}$ The other to win the same youth to finance the movement. Once this is understood, it is seen without difficulty why "great harvest" is expected of the disciples. Harvest means new Christians or to use the Children's terminology: spiritual babies. According to what is said above, there can be no doubt that the Children are under constant pressure to win new members. Without the newcomer's financial support, the movement would come to a halt. It is my opinion that this is the reason why they are loosening up their sex ethics. 1971 Time $^{53}$ reported that the Children of God had drawn 8000 people to a "Sweet Jesus Rock Concert at Stanford University. The Jesus people almost lost the crowd when one evangelist told the collegians they should abstain from sexual immorality and that means abstain except in marriage. We're finding this is the last area people want to give up." The change in attitude towards sex is best explained if it is assumed that that group of the population willing to accept the hard line no longer provides the necessary number of members to keep the group alive. Since they constantly need to win new people, they have to enlarge their radius of action and to adapt their message to the wishes of these listeners. As this larger group seems to be unwilling to accept the harder line, the Children have to give up some of their demands.

To gain a foothold in Bergen is difficult, I learned from the Bergen family, because Norway is such a religious country. They told me it was much easier to establish a group in Denmark. "There we were even supported by the local authorities." ${ }_{54}$ Nevertheless, the group has managed to settle in Bergen. The colony rents a house. They finance their existence according to the usual pattern, by selling books and pamphlets, and from casual gifts and gifts from parents besides what new members may contribute. None of

\footnotetext{
51 Ib.

52 Moses 1973, 53.

${ }^{53}$ Time, 1971, June 21st.

${ }_{54}$ Abel, interview, 1974, June 11th.
} 
the group is working and they don't receive any kind of official support.

Their daily life is centered around training and work. They start the day with common prayer, followed by housework. After a certain free time, classes are held. These too begin with common prayer. The classes serve to train new members by studying the movement's Program "Revolution for Jesus", the Bible and the Mo-letters. There are different kinds of these letters. I have been told that some are used for distribution only, others for the training of members, while there are special letters of edifying character. Omdal ${ }^{55}$ on the other hand, offers the following classification:

1. letters only meant for members of Berg's family

2. for top leaders

3. for the training of leaders

4. for new members

5. for the general public.

They work by appearing in special places in town, such as outside the big stores and the bus-station. To distribute the Mo-letters they need police permission. In Bergen they have no difficulty in obtaining it, since the relationship between the Children and the police is good. When offering their brochures they talk to people, asking them questions like "what do you think of life?" and "do you believe in God?"'56 They invite people to come to their house. Sometimes they use music. "Music is our major ministry, it is the key to the heart of the young, they admire the pop-bands, therefore our music is similar to theirs. But the words in our songs tell something. " ${ }_{57}$ Another aspect of their "wholehearted work for the revolution is to do what we may for our neighbour". ${ }^{58}$ More precisely this means that they take care of young people in trouble, especially drug-addicts and alcoholics. The Children take them to their place, where they meet an atmosphere of joy, love and understanding. They talk to them about Jesus, urging them to let Jesus enter their hearts. They claim to have at least got some of them off drugs.

Afternoon and evening are spent with classes and meetings, attending them is obligatory for the members.

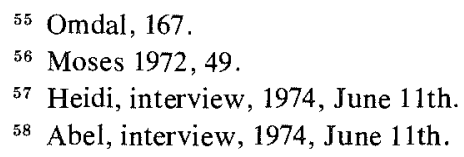


Not all the members of a family stay permanently in the same town. They are sent by headquarters in Oslo to where they are needed. When possible, allowance is made for personal wishes as far as these travels are concerned.

The Children have no contact with other religious organisations in Bergen. "The church does not love us", Abel states, "and very often we are accused of hating our parents", a thing utterly denied by the Bergen family.

Since the Children are a youth-movement, one should think they would try to get into contact with other youth-organisations of the great religious groups in Bergen such as Indre Misjon, Misjonsselskapet, Misjonssambandet or the Salvation Army. But that is not the case. The Bergen family is not interested in establishing relations with these groups.

As already mentioned, the group in Bergen is increasing. That should suggest they have something to offer that appeals to young people, especially to those who are not firmly rooted in a different milieu, a Christian organisation or a sportclub. In all events, the Children seem to appeal to youngsters unhappy with and frustrated by the lives they lead. Mirjam was unable to fulfill the demands of her job, Lystra was early "searching for truth", Berenica had been on drugs. What attracts these young people is the joy and love they see among the Children. "Their faces shone-and I followed them", 59 "the love they have, the light in their eyes", 60 this fascinates them and carries them away, they want to share it, because they lacked love and warmth. 'I am amazed at how many people I've counseled who have never heard their fathers say 'I love you', declares baptist-minister John Bisagno, ${ }^{61}$ when asked to explain the success of the movement.

In America the Children have been accused of using drugs or hypnosis in order to cause conversion and during instruction. However, this has been impossible to prove. One would rather agree with Heidi, "we read the Bible so much, that we speak it'". Their occupation with the Bible and the Moletters is so intense that it forms their thinking and speech and leads to "the absolutism of the Jesus revolution and complete dependency. The Jesus trip gives them rich expectations and more rigid values, they also suffer a narrowing of conceptual vision; they become obsessed.' ${ }^{\prime 2}$ Even if the Bergen group does not impress one as being obsessed, still one feels justified to

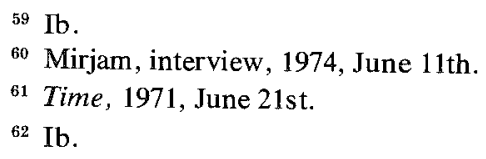


speak of a certain "narrowing of conceptual vision" as far as they are concerned. This narrowing shows itself in their attitude towards the Mo-letters. According to Heidi these epistles amount to spiritual food. They are convincing because they lead deeper into the Bible. The letters are concerned with the spiritual world, an expression which is the basis for the following formulation: "We are tools in God's hand, fighting against the devil." Terms like spiritual values, things and spiritual world, occurred very often during the interview. The spiritual world is the real one. This conception provides their basic point of orientation. The spiritual world consists of God, devil and spirits, the latter can be divided into good and evil ones. The spirits are given certain areas of which they are in charge. But the rule of the spirits is limited, they are subject to the rule of God. "Everything happens in the spiritual world. What happens on the surface is nothing but a small physical manifestation of the real action. It's in the spiritual world the real action goes on and is completely under control." "63

This outlook determines the Children's reaction to what we call reality and dominates their position over against this world. ${ }^{64}$

After this general description of the Children of God it is possible to proceed in various ways. One could take up the different criticisms the movement has met with, or inquire more deeply into the sociological cause for the group's existence; another approach would be to compare the Children of God with earlier protest-movements in the Chruch. Since the Children can also be characterised as a missionary movement, I want to take up their view of the Bible and the Mo-letters. These scriptures form the basis of their theology. Furthermore I will try to indicate how they use these texts.

In the program of the movement, "Revolution for Jesus", ${ }^{65}$ Moses explains the role of the Bible: "The Bible is divided into two parts, the Old Testament and the New Testament. The Old Testament can be divided into three parts: HISTORY, 1. Mos.-Esther, POETRY from Job to Song of Songs, PROPHECY from Isaiah to Malachi. The New Testament is concealed in the Old and the Old is revealed in the New. The way we look at it, we can divide the Bible into five parts.

\footnotetext{
${ }^{63}$ Mo-letters, 1973, Aug. 29th, § 65.

${ }^{64}$ Cf. Moses 1972, 13. [Ed.: Collmar 1974, 8 ff; 1975, 16f.]

${ }^{65} \mathrm{Ib} ., 23$.
} 
1. OT preparation (for the coming of the Messiah, Jesus), Is. 53.

2. The four gospels, Manifestation (of Messiah Jesus), Luke 24, 44.

3. The Acts of the Apostles, Spreading (the gospel is spread), Acts 1.8.

4. The letters or epistles, explanation (explain other parts of the Bible), Rom. 3.21.

5. Revelation, consummation (the latter days), Rev. 1.7."

All the parts together form the loveletter written by the Creator of the universe. This formulation means more than just a somewhat strange description of the Bible. It serves to keep the attention of the members fixed on the holy book: If a member gets tired of the constant memorising of Bible verses, he or she should remember that they "just received a letter (Bible) from the Creator of the universe" ${ }^{66}$ As is generally known, there exist quite a number of Bible editions. But these are not equally valued by the Children. They only accept the King James Version (KJV). Why just this one? The answer is given in the program: "The King James Version was translated by fundamentalists at a time when heretics were burnt at the stake and the English language was most beautiful and pure, the time of Elizabeth I and Shakespeare. The KJV has become the most used in the world today and sells more than all the other translations taken together [...] it has stood the trial of time. Furthermore, KJV has no copyright as most of the later translations have which shows that it was not translated for mercenary reasons." ${ }_{67}$ Moses even refers to the Dead Sea Scrolls and claims "they demonstrate also that $\mathrm{KJV}$ is a unique, almost supernaturally precise translation". ${ }^{68}$ But the best reason to use KJV is that it works! According to the Children, a passage read in this version is more apt to bring fruits than the same passage read in a modern translation. The outline of their view of the Bible culminates in the following: "We believe that the KJV was inspired."'69 What is presented here is nothing special for the group, these views have been and partly still are acknowledged in many churches.

Already at this point, it is necessary to pronounce several objections. Their view is given in generalised, oversimplified statements without any convincing justifications. A sentence such as "the NT is concealed in the

\footnotetext{
${ }^{66} \mathrm{Ib}, 42$

${ }^{67}$ Ib., 23.

${ }^{68} \mathrm{Ib}$.

${ }^{69} \mathrm{Ib}$.
} 
$\mathrm{OT}$ and the OT is revealed in the $\mathrm{NT}^{\text {"70 }}$ says nothing about the character of the Bible, it is already an interpretation of it and it compells its adherents to read this book in a certain manner. This idea pays no attention to the distinctive quality of each single book in the Bible. It overlooks the differences of time between the Testaments and it neglects the problems each author of a book was concerned with. The same objections apply also to their division of the Bible. Again because of oversimplification the statement that the OT is the preparation for the Messiah is wrong. What can be said, is that some New Testament authors have interpreted a few, especially prophetic sayings, as speaking about Christ.

The epistles are characterised as explanations of other parts of the Bible. This gives a completely false impression of this important part of New Testament literature. To do justice to the epistles, they must be viewed as autonomous documents, written on special occasions, either to solve certain problems in certain congregations as e.g. Galatians and Corinthians, or to give information about a form of theology, as Paul does in his letter to the Romans. More examples could easily be given. It may happen that these letters throw light on other biblical texts. This is however not a simple question. In all events this is not the main purpose of the letters. If the epistles seem to explain other texts, then by the usage they make of them. And this fact is more revealing for the writer than that it throws light on the original meaning of the text made use of.

The great veneration for the KJV stems from four facts:

a. it was translated by fundamentalists

b. the translation was made in Elizabethan times

c. the testimony of the Dead Sea Scrolls

d. it was inspired.

But how can these facts have any bearing on the value of the translation. To begin with, Moses says nothing about the sources from which this translation was made. Trustworthiness could only be claimed if it could be shown that the texts from which the translation was made were of high quality. The use of the expression "fundamentalists" in this connection is an anachronism. As is well known, fundamentalism is a movement that came into being in America in the 1870's aiming against the theological liberalism, such a mistake does not strengthen one's trust in Moses' argument.

${ }^{70} \mathrm{Ib}$. 
One may, indeed, find out that fundamentalism is "characterised by a doctrinal aversion to methods and results of natural sciences and historical research" ${ }^{\prime 71}$ and then assume that it is that which Moses thinks distinguished the translators of KJV. But how much were natural sciences and historical research developed in Elizabethan times?

And how is the beauty and purity of the English language supposed to establish the authenticity of the translation? Nor does the reference to the Dead Sea Scrolls serve this purpose. The Scrolls don't demonstrate "a nearly supernaturally precise translation". What they do, is to give evidence that the lower date of the redaction of the Old Testament may be put at the 3rd century before Christ. And the Scrolls of Isaiah and Habakuk confirm in general the exactness of the Masoretic text. ${ }^{72}$ The bearing of the scrolls on the New Testament is of a completely different character than Moses assumes in his "class" on the Bible. There are relations between the Essenes and the New Testament. John the Baptist, Jesus and the beginnings of the church lived rather near the Essenes both in time and place. And it is generally assumed that John the Baptist had connections with the Essenes. But of what kind these relations were is not agreed upon by the scholars. There exist certain similarities between the teachings of the Essenes and that of Jesus, but also great differences. It may suffice to mention the attitude towards the Torah. Both the Teacher of Justice and Jesus sharpen the contemporary understanding of the Law. But in very different ways. The first lays greater stress on casuistics, while Jesus protests against the limited meaning of the Law caused by the casuistic application.

Moses, the founder of the Children of God, wants to establish the authority of the KJV. He tries to reach this goal by the arguments given above. His trumpcard in the line of argument is the theory of inspiration, more precisely verbal inspiration: "Even if the Bible is written by men, this means only that God used a tool to write the Bible. God put His word in the writer's mouth, or the writers were driven by the Holy Spirit. Sometimes the prophets did not understand what they were writing." ${ }_{73}$ This is in agreement with his assumption of the intimate connection between the Testaments and his basical view of the Bible as the History of the Messiah. The

\footnotetext{
71 Ahlstrom, 1179.

72 Oral communication by Dr. B. Jongeling, Qumran Institute, Groningen, 1974, July 16th.

${ }^{73}$ Moses 1972, 23.
} 
uncritical use of the doctrine of inspiration weakens his argument and what is worse, leads to a narrow conception of the Bible. The same narrowness shows itself in Moses' further statements as: "The main subject of the Bible is the word and that is Jesus." 74 This identification is a result of the following consideration: "Synonyms are words which have the same meaning. 'Jesus' and 'word' are synonyms. The Bible is Jesus on Paper."

In spite of their stressing that the Bible is a whole, they don't follow it. "The whole" consists of what can be brought under the heading "the "Bible is Jesus on Paper',".

As a conclusion it may be said that the Bible according to the view they take of it, represents an indisputable source of authority aimed in two directions: One is to keep the members of the Children in the fold and in agreement with the rules. This is reached by constant insistance on the importance of obedience and subordination towards the leaders. Their, the leaders', authority is given them by God. "We shall obey and submit to these older members, because God put them over us." 75 Why that is so is said in Heb. 13.7: "Remember them which have the rule over you, who have spoken unto you the word of God: whose faith follow, considering the end of their conversation." "Jesus is the highest SHEPHERD and the elders are undershepherds, personally appointed by him." 76

Whenever the Mo-Letters call for obedience and subordination, these calls are supported by biblical quotations. But authority is not only directed and exercised inwards, their prophet's view of the Bible makes it possible to act with authority when the Children are working as missionaries or fulltime revolutionaries. Because whatever they say or do, can finally be traced back to God himself who is speaking through the leaders. This conviction assures them of the righteousness of their doings and on the other hand leaves no possibility for argument. If anyone refuses to listen ' don't waste your time $[. .$.$] go!'”7$

It has already been mentioned that the Mo-letters are highly valued by the Children. According to the Children, they are the Bible of our generation as Moses is the prophet of this same generation. The letters are printed in the same manner as older editions of the Bible, in verses which are numbered.

\footnotetext{
${ }^{74}$ Ib., 24.

75 Ib., 33.

${ }^{76} \mathrm{Ib}$.

${ }^{77} \mathrm{Ib} ., 50$.
} 
The opening phrases often remind one of the Pauline phrasing of epistles. Already these formalities serve to establish the authoritative character of the Mo-letters. Their authority is further strengthened by the supposition that they are inspired. That means they are often the result of a "revelation". E.g.: "The promised Land", "The Baha'i Temple Prophecy", "Europe" and "The Green Door", etc. A sentence such as "Thank you for your letter, concerning some of our latest radical writings. I am sorry that some of these were 'a hard saying' for you'"78 shows at least that Moses compares his words with the sayings of Jesus.

In trying to answer the question how they make use of the Bible, I start with Moses' characteristic of the Gospel of John, which is called:

"The real Jesus in dear John., "79

This "class" gives to begin with a reference to the gospel; then follows Moses' comment or interpretation, followed again by further biblical references; this scheme is applied to the whole gospel, chapter by chapter. The number of initial verses taken from each chapter varies from 2 to 5 verses. The first verse given is: 1.12: "But as many as received him, to them gave he power to become the sons of God, even to them that believe on his name." The comment of Moses: not all are sons of God. The further references: 8.44: "Ye are of your father the devil, and the lusts of your father ye will do."

Rev. 13.8: "And all that dwell upon the earth shall worship him, whose names are not written in the book of life of the Lamb slain from the foundation of the world." And it continues with Rev. 20.15: "This is the second death. And whosoever was not found written in the book of life was cast into the lake of fire."

Already in this opening collection of quotations their view of the Bible as a means to establish authority is practised. John 1.12 defines their own position, the group are the sons of God, because they have received him, they have "asked Jesus to come into their hearts". ${ }^{80}$ From here they proceed to decide who the others are: "Your father is the devil." And what that means is shown by the quotations from Rev. The Sons of the Devil don't have their names written in the book of life and will be thrown into the lake of fire.

\footnotetext{
${ }^{78}$ Mo-letters, 1973, Dec. 22nd, §1.

${ }^{79}$ Moses 1972, 45.

${ }^{80} \mathrm{Ib} ., 10$.
} 
Is this what is intended by the prologue of John? It states already in the opening verses that the word was God, that all things were made by him, that the word came unto his own, but his own did not receive him. At first sight, the difference between the prologue and Moses seems not so great. But c'est le ton qui fait la musique! If we only had the statements of Moses, then the gospel of John would begin with a manifestation of two groups, the sons of God and the sons of the devil, it would present the unbridgeable gap between them and indicate that the latter would finally be completely destroyed.

The prologue however tells something different, it goes farther back in time and relates that this world was made by and belongs to God who in those days sent his son to save mankind. The same thought it expressed by C. H. Dodd: "I have tried to show that whatever else the Logos of the Fourth Gospel is, on one side it is the Word of the Lord, by which the heavens were framed, which came through the prophets to Israel, was rejected by the people at large, but found acceptance with the faithful remnant, to whom it gave the status of God's children." 81 The point is that Moses, by cutting away the opening verses of the prologue, completely changes the meaning of the verse he quotes. According to John, people have sinned, but some have been faithful, and by receiving the logos they got the possibility to become sons of God; this, however, is nothing for them to be proud of or that gives them the right to condemn others, because these others have just the same possibility as they have, even they may receive the Word and will thereby get the status of sons of God.

Having defined their positions as sons of God, the Children read the whole gospel in accordance with this idea. The miracle in Cana justifies their opposition against the system. What the system has to offer, gets worse, the wine of Jesus gets better. This is supported by Prov. 4.17-18: "They eat the bread of wickedness and drink the wine of violence. But the path of the just is as the shining light, that shineth more and more unto the perfect day." The method is the same as in the first example and throughout the rest of the gospel. The verses are picked to justify themselves as a movement of God, to establish the authority of the leaders, to enforce the obedience of the members and to provide the necessary assurance for successful "missionary work".

81 Dodd, 294. 
The best example is John 15.8: "Herein is my Father glorified that ye bear much fruit; so shall ye be my disciples." Again the phrase is taken out of its context and explained according to their view. "Much fruit" is a demand on the disciples. So far it does not go against John, but then the thought is switched again. Fruit are new disciples. I have touched upon this earlier and could easily quote from several of the Children's writings; let one suffice: "Look at the result of their (the leaders). work (which is thousands of ardent disciples)." ${ }^{2}$ Moses supports this statement again by another quotation, this time taken from Matt. 13.8: "But other fell into good ground, and brought forth fruit." And Rom. 16.5: "Likewise greet the church that is in their house." Surprising however, in the following statement, fruit has nothing to do with Gal. 5.22. The situation is the same as in the first example. Moses' reasoning is false, because he neglects the context of 15.8. In order to arrive at a correct understanding of 15.8 it is necessary to start with the opening verses of the 15th chapter: "I am the true wine and my Father is the husbandman", v. 4: "Abide in me, and I in you", v. 5: "I am the wine, ye are the branches: he that abideth in me, and I in him, the same bringeth forth much fruit; for without me ye can do nothing." Correct exegetical procedure would be to draw in the other "ego eimi" -sayings too and to establish the relationship of these passages with the prologue, where the main theme of the gospel is indicated "In him was Life". John sees the possibility of real life only in connection with Jesus. Therefore the "meinate en emoi" is so important, without it no fruit would be possible at all. What the fruit is, is not said expressis verbis, but so much can be seen from the text that it is a result of the life made possible by the Logos. Fruit in the Johannine context characterises the believer: "The relationship with God means disturbance of human security-for the believer too. It gives no restful possession [...] but demands movement, growth; its law is the karpon pherein. $" 83$

The main idea in John is, that the Son has the same life as the Father and that only through the Son is mankind able to participate in the divine Life. But the Children of God give this passage a totally different explanation: fruit $=$ new disciple. And I have the suspicion that they are forced to interpret it this way. This special understanding of the term "fruit" was already mentioned in connection with the Children's loosening up their sex

\footnotetext{
${ }_{82}$ Moses 1972, $34 \mathrm{f}$.

83 Bultmann, 409.
} 
ethics. If we recall what was said about the Children's need constantly to gain new members, we understand why they oppose an interpretation of "fruit" in accordance with Gal. 5.22 or Matt. 3.8. According to their "method" of pick and choose, they could have used these verses too. Such interpretations would not further the growth of the movement. Instead the members of the group are constantly confronted with what is supposed to be God's demand on them. The demand is not to be doubted, because it goes back to the inspired Bible, and he who does not obey the Jesus on Paper, has not received him into his heart, he is a son of the devil to be thrown into the lake of fire.

Concluding, we may say that the group both views and uses the Bible as a means to establish indisputable authority within and outside the movement. "Obey your parents (in the Lord) in everything. If they "make an error' God has nevertheless to reward your faith! It is better for you to follow one of God's leaders who has 'made a mistake' than to trust your own wisdom-which is to trust human beings (yourself) this makes only for a curse. Could you have done better? If not, follow humbly that you may not be found fighting against God." 84

\section{Bibliography}

Ahlstrom, S., 1958, Fundamentalismus. Die Religion in Geschichte und Gegenwart 3. Tübingen.

Bultmann, R., 1956, Das Evangelium des Johannes. Göttingen.

[Collmar, L., 1974, Guds barn 1. Vår kyrka 49.

- 1957, Guds barn 2. Var kyrka 1. Editor's note.]

Dodd, C., 1963, The Interpretation of the Fourth Gospel. Cambridge.

Moses, D., 1972, Revolution for Jesus. København.

- 1973, Om à overleve. S.1.

Omdal, S., 1974, Children of God. Stavanger.

[Schmidt, P.-H., 1975, Children of God-Guds barn? Ad lucem 66. Editor's note.]

Periodicals:

Newsweek, 1971, Nov. 22nd.

Time, 1971, June 21st.

Time, 1972, Jan. 24th.

Time, 1974, Feb. 18th.

Mo-letters:

1970, Nov. 15th, Baha'i Tempel profeti.

1971, Feb. 4th, Det lovede landet.

1973, Aug. 29th, Den grönne döra.

1973, Nov. 11th, Europa.

1973, Dec. 22nd, Mamma heng på, brenn din Behå.

${ }^{84}$ Moses 1972, $34 \mathrm{f}$. 